\title{
BATS AND THEIR ROLE IN HUMAN RABIES EPIDEMIOLOGY IN THE
}

\section{AMERICAS}

\section{DANTAS-TORRES F. (1)}

(1) Aggeu Magalhães Research Center, Oswaldo Cruz Foundation, Recife, Pernambuco State, Brazil.

ABSTRACT: Bats are very interesting animals: they are the unique flying mammals, have developed a highly sophisticated echolocation system, and have become specialized to eat different types of diets. Hematophagous (vampire) bats are those specialized to feed solely on blood and have served as a source of inspiration for researchers as well as for writers. Vampire bat attacks on humans have moved from the realm of science fiction to reality in Latin America and bats (including nonhematophagous ones) have assumed an important role in the transmission of rabies virus to humans. This article discusses the emerging role of bats as rabies virus transmitters, with particular emphasis on the role of hematophagous bats in the epidemiology of human rabies in Latin America. Possible reasons associated with the increasing risk of exposure to bats in this region are also discussed.

KEY WORDS: rabies, epidemiology, disease transmission, Chiroptera.

CONFLICTS OF INTEREST: There is no conflict.

\section{CORRESPONDENCE TO:}

FILIPE DANTAS-TORRES, Centro de Pesquisas Aggeu Magalhães, Fundação Oswaldo Cruz, Av. Moraes Rego s/n, 50670-420, Recife, PE, Brasil. Phone: +55 81 21012640. Fax: +55 81 34532449. Email: fdt@cpqam.fiocruz.br. 


\section{INTRODUCTION}

Bats are wonderful and interesting animals that belong to the mammalian order Chiroptera, which means "hand-wing". Bats are ecologically important (e.g. they are the only major predators of night-flying insects), they are the only true flying mammals, they have a highly sophisticated echolocation system (20), and they are great nutritional specialists - that is, they have become specialized to eat different types of diets. However, when close to humans, bats may cause disturbance and risk of transmission of pathogens (28). It is not rare to see large colonies of bats close to humans in urban areas and the interaction between bats and people can eventually result in disease transmission to humans (17). Bats are known vectors of pathogens, such as the rabies virus and the fungus Histoplasma capsulatum. Additionally, there is evidence that bats may be acting as reservoirs of the Ebola virus (13) and other emerging viruses (4).

For quite some time, bats have served as a source of inspiration not only for researchers but also for writers. A number of books and films, such as the best seller "Dracula", have been produced based on vampire myths. It is particularly true for vampire (hematophagous) bats that are professional blood suckers and have nocturnal habits and an unfriendly appearance. Vampire bat attacks on humans have moved from the realm of science fiction to reality, particularly in Latin America $(2,5$, $11,14,16,18,23,26)$. As a consequence, human rabies transmitted by vampire bats has emerged as a challenge to public health authorities of subtropical and tropical areas of the Americas, including the Caribbean $(3,23,32)$.

This article discusses the emerging role of bats as rabies virus transmitters in the Americas, with particular emphasis on the role of hematophagous bats in the epidemiology of human rabies in Latin America.

\section{BATS AND RABIES TRANSMISSION IN THE AMERICAS}

Bats have long been implicated as rabies virus vectors $(6,12)$ and have assumed an important role in the epidemiology of human rabies in the Americas, particularly in the past 20 years $(3,23,25)$.

Rabies is a life-threatening infectious disease caused by a virus of the order Mononegavirales, family Rhabdoviridae, and genus Lyssavirus. This zoonosis is almost invariably fatal (31) and affects various species of animals worldwide. In the 1980s, the Pan American Health Organization Member States decided to eliminate 
human rabies transmitted by dogs in the region of the Americas by 2005 (21). As a result of the efforts, human and canine rabies cases experienced a $90 \%$ reduction during the past 20 years (3). In the same period, however, bats assumed an important position among the most important rabies virus vectors to humans (3). In 2004, only 20 human rabies cases transmitted by dogs were recorded in Latin America. In contrast, 71 cases of human rabies transmitted by other animals were reported during the same period and some $65 \%$ of them were transmitted by hematophagous bats (25).

In the Americas, cases of human rabies transmitted by bats surpassed those transmitted by dogs $(3,25)$. The cumulative number of human rabies cases transmitted by bats in Brazil from 2001 to 2006 was larger than the number of cases transmitted by all other rabies virus transmitters (i.e. dogs, cats and others - Table 1). During this period (2001-2006), 53 human rabies cases transmitted by dogs were notified in Brazil, while 47 human rabies cases transmitted by bats were notified only in 2005.

It is interesting to note that the transmission of rabies virus to humans has not been exclusively made by hematophagous bats. Over the past two decades, a number of human rabies cases transmitted by non-hematophagous bats, mainly frugivorous and insectivorous, were recorded in the region of the Americas $(3,10,11,15,19,30)$. From 1993 to 2002, 168 cases of human rabies transmitted by bats were recorded in 15 American countries and 27 of these cases were transmitted by nonhematophagous bats (3). In Brazil alone, at least 28 species of bats (Table 2) had been found naturally infected by the rabies virus $(7,29)$. Despite this, the transmission of the rabies virus to humans by non-hematophagous bats is likely to be associated with an accidental exposure, owing to an undue manipulation of infected bats. Bats should never be handled, particularly those seen roosting outside during daylight hours or found on the ground, because they may be infected by the rabies virus.

Fortunately, the proportion of people bitten by vampire bats that have acquired rabies is relatively low $(3,24)$. For instance, in two outbreaks of human rabies transmitted by vampire bats in the state of Bahia (Northeastern Brazil), in 1991 and 1992, out of 313 people bled by vampire bats only five died from rabies (11). Two outbreaks of bat-transmitted human rabies in remote, rural areas of the state of Pará (Brazilian Amazon), where 21 people died due to paralytic rabies, have recently been 
described (22). In the municipality of Portel, where 15 out of the 21 fatal cases were recorded, a total of 1,558 inhabitants reported more than one episode of vampire bat aggression in the year before the outbreak. This suggests that the risk of rabies virus infection in humans is probably dependent on factors such as the rate of infection in the bats rather than the frequency of the bat attacks.

The risk of acquiring rabies is remote when adequate prophylactic measures are adopted. It is important to remember that the World Health Organization classifies exposure to bats as Category III, which means severe exposure, and recommends immediate administration of rabies immunoglobulin and vaccine (32). The low incidence of rabies in people bitten by bats is probably also due to the fact that the rabies post-exposure prophylaxis has been achieved in most of the cases.

\section{HEMATOPHAGOUS BATS: SPECIES, BEHAVIOR AND DISTRIBUTION}

As previously commented, bats are the only true flying mammals; flying squirrels do not really fly, i.e. they glide. Moreover, hematophagous bats are the unique chordates (phylum Chordata) truly specialized to feed solely on blood; the South American fish 'candiru' feeds on blood but also on bits of flesh. As far as it is known, there are three species of hematophagous bats: Desmodus rotundus, Diaemus youngi and Diphylla ecaudata. These three species belong to the family Phyllostomidae and are found exclusively in Latin America, from Mexico to the Northern provinces of Argentina (16).

Desmodus rotundus, popularly known as the common vampire bat, is the most widespread of all hematophagous bats. Although the common vampire bat occasionally feeds on birds, it is specialized to feed on mammals (16) and thereby is the species of epidemiological importance (3). It is well known that the common vampire bat plays an important role in the epidemiology of bovine paralytic rabies in rural areas (16). Additionally, the risk of outbreaks of attacks on dogs and humans is increasing in the urban zone, where the natural sources of blood for the common vampire bat are either scarce or non-existent. This is particularly true in Brazil $(1,8$, $9,16)$. Considering that dogs are often near or in human habitations, vampire bat attacks on dogs can be used as a risk indicator for attacks on humans.

Diaemus youngi (common name: the white-winged bat) and Diphylla ecaudata (common name: the hairy-legged bat) are relatively rare species that prefer to feed 
on birds, such as chickens (27). Eventually, the hairy-legged bat feed on cows and pigs. These two species play no important role in the epidemiology of human rabies.

\section{INCREASING RISK OF VAMPIRE BAT ATTACKS: POSSIBLE DETERMINANT FACTORS}

In recent years, there has been an increasing risk of vampire bat attacks in Latin America $(5,14,18)$, which has been clearly demonstrated in Brazil $(2,11,22,24$, 26). For instance, the State of Pernambuco (Northeastern Brazil) has recently witnessed its first urban outbreak of vampire bat attacks on humans, in which 20 attacks were recorded in only 13 days. This is quite high for an area not previously defined as an 'at risk' one. At this time, there is no explanation for why this is happening, although it is likely that various factors might be involved. The unplanned, rapid urban growth has led bats to colonize new ecological niches and leave their "caverns" to occupy human-made environments. Similarly, the deterioration of nature and depletion of natural resources for food might be encouraging vampire bats to seek new alternatives, such as humans.

In Latin America, the frequency of vampire bat attacks on humans is influenced by human actions, such as the removal or relocation of livestock, deforestation, and gold mining $(2,24,26)$. At least in theory, there is also a possibility that vampire bats are becoming anthropophilic. Why should this be happening? Could it be a response of the bats against human pressure? Probably yes. But the question is: Why humans? Humans are numerous, they present diurnal habits, and they have developed no natural defense mechanisms against vampire bats, especially at night when these nocturnal predators hunt for blood. In the same manner, most of the human habitations are easy for bats to access. If vampire bats are really becoming more anthropophilic, the aspects aforementioned are probably important determinant factors.

\section{FUTURE DIRECTIONS}

Henceforth, Latin American countries must be politically astute, especially where cases of vampire bat attacks on humans have been reported. Decentralization of actions to control bats in urban areas is crucial to improve the capacity of the public health workers to react, particularly in outbreak situations. The control of bats is not so easy and has serious implications for wildlife conservation. 
It is mandatory to guarantee post-exposure treatment to all individuals exposed to bat aggressions, even in remote areas. Finally, but not less important, it is essential to emphasize the importance of environmental education. Communities at risk of vampire bat attacks must be informed about the role of bats - e.g. dispersion of seeds - in different ecosystems. This will be crucial to avoid an indiscriminate culling of bats. Certainly, the ultimate goal of a program for the prevention of human rabies transmitted by bats is not to exterminate the bats, but to achieve a balance between human needs and nature's needs.

\section{EPILOGUE: A LESSON FOR THE PRESENT AND FUTURE GENERATIONS}

Bats and their link with human rabies transmission represent a multifaceted and emerging public health problem that requires further research and a worldwide mobilization. Maybe the most important lesson coming out of this issue is something already known, though often forgotten or neglected: conservation and preservation of natural resources is vital, not only for the wildlife but also for human health. This is a major lesson for the present and future generations.

Table 1. Cases of human rabies notified in Brazil, from 2001 to 2006, according to the animal aggressor*.

\begin{tabular}{lcccccccc}
\hline \multirow{2}{*}{ Animal aggressor } & \multicolumn{6}{c}{ Year of notification } & Total \\
\cline { 2 - 7 } & $\mathbf{2 0 0 1}$ & $\mathbf{2 0 0 2}$ & $\mathbf{2 0 0 3}$ & $\mathbf{2 0 0 4}$ & $\mathbf{2 0 0 5}$ & $\mathbf{2 0 0 6}$ & \\
\hline Bats & - & 1 & 4 & 25 & 47 & 2 & 79 \\
Dogs & 20 & 9 & 15 & 3 & 1 & 5 & 53 \\
Others & - & 1 & - & - & - & 3 & 4 \\
Cats & 1 & - & 1 & 1 & - & - & 3 \\
Not specified/Ignored & 1 & - & 3 & 5 & - & 1 & 10 \\
\hline
\end{tabular}

*Data from the Brazilian Disease Notification System (SINAN). 
Table 2. Species of bats that have been found naturally infected with the rabies virus in Brazil, according to their feeding habits $(7,29)$.

\begin{tabular}{|c|c|}
\hline Feeding habit & Species \\
\hline Insectivorous bats & $\begin{array}{l}\text { Eumops auripendulus, Histiotus velatus, Lasiurus } \\
\text { borealis, Lasiurus cinereus, Lasiurus ega, Lonchorhina } \\
\text { aurita, Micronycteris megalotis, Molossus molossus, } \\
\text { Molossus rufus, Myotis nigricans, Nyctinomops } \\
\text { laticaudatus, Nyctinomops macrotis, Tadarida } \\
\text { brasiliensis, Tonatia brasiliense. }\end{array}$ \\
\hline Frugivorous bats & $\begin{array}{l}\text { Artibeus fimbriatus, Artibeus jamaicensis, Artibeus } \\
\text { lituratus, Artibeus planirostris, Carollia perspicillata, } \\
\text { Platyrrhinus lineatus. }\end{array}$ \\
\hline Nectarivorous bats & $\begin{array}{l}\text { Anoura caudifer, Anoura geoffroyi, Glossophaga } \\
\text { soricina. }\end{array}$ \\
\hline Omnivorous bats & Phyllostomus hastatus. \\
\hline Carnivorous bats & Chrotopterus auritus, Trachops cirrhosus. \\
\hline Hematophagous bats & $\begin{array}{l}\text { Desmodus rotundus, Diaemus youngi, Diphylla } \\
\text { ecaudata. }\end{array}$ \\
\hline
\end{tabular}

\section{ACKNOWLEDGEMENTS}

F. Dantas-Torres is the recipient of a PhD scholarship from the Coordination for the Improvement of Higher Education Personnel [Coordenação de Aperfeiçoamento de Pessoal de Nível Superior - CAPES]. 


\section{REFERENCES}

1 ALMEIDA EO., MOREIRA EC., NAVEDA LAB., HERRMANN GP. Combate ao Desmodus rotundus rotundus (E. Geoffroy, 1810) na região cárstica de Cordisburgo e Curvelo, Minas Gerais. Arq. Bras. Med. Vet. Zootec., 2002, 54, 117-26.

2 BATISTA-DA-COSTA M., BONITO RF., NISHIOKA SA. An outbreak of vampire bat bite in a Brazilian village. Trop. Med. Parasitol., 1993, 44, 219-20.

3 BELOTTO A., LEANES LF., SCHNEIDER MC., TAMAYO H., CORREA E. Overview of rabies in the Americas. Virus Res., 2005, 111, 5-12.

4 CALISHER CH., CHILDS JE., FIELD HE., HOLMES KV., SCHOUNTZ T. Bats: important reservoir hosts of emerging viruses. Clin. Microbiol. Rev., 2006, 19, 53145.

5 CARABALLO-H AJ. Outbreak of vampire bat biting in a Venezuelan village. Rev. Saúde Publ., 1996, 30, 483-4.

6 CARINI A. Sur une grande epizootie de rage. Ann. I'Inst. Pasteur., 1911, 25, 843-6.

7 CUNHA EMS., LARA MCCSH., NASSAR AFC., SODRE MM., AMARAL LFV. Isolamento do vírus da raiva em Artibeus fimbriatus no Estado de São Paulo. Rev. Saúde Publ., 2005, 39, 683-4.

8 DANTAS-TORRES F., VALENÇA C., ANDRADE FILHO GV. First record of Desmodus rotundus in an urban area from de city of Olinda, Pernambuco, Northeastern Brazil: a case report. Rev. Inst. Med. Trop. São Paulo., 2005, 47, 1078.

9 ESBÉRARD CE. Observações sobre o ataque de morcegos hematófagos a cães. Rev. Bras. Med. Vet., 1999, 21, 219-20.

10 FAVORETTO SR., CARRIERI ML., CUNHA EM., AGUIAR EA., SILVA LH., SODRE MM., SOUZA MC., KOTAIT I. Antigenic typing of Brazilian rabies virus samples isolated from animals and humans, 1989-2000. Rev. Inst. Med. Trop. São Paulo., 2002, 44, 91-5.

11 GONÇALVES MA., SA-NETO RJ., BRAZIL TK. Outbreak of aggressions and transmission of rabies in human beings by vampire bats in Northeastern Brazil. Rev. Soc. Bras. Med. Trop., 2002, 35, 461-4.

12 HAUPT H., REHAAG H. Raiva epizoótica nos rebanhos de Santa Catarina, sul do Brasil, transmitida por morcegos. Bol. Soc. Bras. Med. Vet., 1925, 2, 17-47. 
13 LEROY EM, KUMULUNGUI B., POURRUT X., ROUQUET P., HASSANIN A., YABA P., DÉLICAT A., PAWESKA JT., GONZALEZ JP., SWANEPOEL R. Fruit bats as reservoirs of Ebola virus. Nature., 2005, 438, 575-6.

14 LOPEZ A., MIRANDA P., TEJADA E., FISHBEIN DB. Outbreak of human rabies in the Peruvian jungle. Lancet., 1992, 339, 408-11.

15 MATTOS CA., FAVI M., YUNG V., PAVLETIC C., MATTOS CC. Bat rabies in urban centers in Chile. J. Wildl. Dis., 2000, 36, 231-40.

16 MAYEN F. Haematophagous bats in Brazil, their role in rabies transmission, impact on public health, livestock industry and alternatives to an indiscriminate reduction of bat population. J. Vet. Med. B. Infect. Dis. Vet. Public Health., 2003, 50, 469-72.

17 MCCALL BJ., EPSTEIN JH., NEILL AS., HEEL K., FIELD H., BARRETT J., SMITH GA., SELVEY LA., RODWELL B., LUNT R. Potential exposure to Australian bat lyssavirus, Queensland, 1996-1999. Emerg. Infect. Dis., 2000, 6, 259-64.

18 MCCARTHY TJ. Human depredation by vampire bats (Desmodus rotundus) following a hog cholera campaign. Am. J. Trop. Med. Hyg., 1989, 40, 320-2.

19 MESSENGER SL., SMITH JS., RUPPRECHT CE. Emerging epidemiology of batassociated cryptic cases of rabies in humans in the United States. Clin. Infect. Dis., 2002, 35, 738-47.

20 NEUWEILER, G. Evolutionary aspects of bat echolocation. J. Comp. Physiol. A: Neuroethol. Sens. Neural. Behav. Physiol., 2003, 189, 245-56.

21 ORGANIZACIÓN PANAMERICANA DE LA SALUD. Estrategia y plan de acción para la eliminación de la rabia urbana en América Latina para el final de la década de 1980. Guayaquil: OPAS; 1983.

22 ROSA ES., KOTAIT I., BARBOSA TF., CARRIERI ML., BRANDÃO PE., PINHEIRO AS., BEGOT AL., WADA MY., DE OLIVEIRA RC., GRISARD EC., FERREIRA M., LIMA RJ., MONTEBELlO L., MEDEIROS DB., SOUSA RC., BENSABATH G., CARMO EH., VASCONCELOS PF. Bat-transmitted human rabies outbreaks, Brazilian Amazon. Emerg. Infect. Dis., 2006, 12, 1197-202.

23 SCHNEIDER MC., ALMEIDA GA., SOUZA LM., MORARES NB., DIAZ RC. Controle da raiva no Brasil de 1980 a 1990. Rev. Saúde Publ., 1996, 30, 196-203.

24 SCHNEIDER MC., ARON J., SANTOS-BURGOA C., UIEDA W., RUIZ-VELAZCO S. Common vampire bat attacks on humans in a village of the Amazon region of Brazil. Cad. Saúde Publ., 2001, 17, 1531-6. 
25 SCHNEIDER MC., BELOTTO A., ADÉ MP., LEANES LF., CORREA E., TAMAYO H., MEDINA G., RODRIGUES M. Situación epidemiológica de la rabia humana en América Latina en 2004. Bol. Epidemiol. OPAS., 2005, 26, 2-4.

26 SCHNEIDER MC., SANTOS-BURGOA C., ARON J., MUNOZ B., RUIZVELAZCO S., UIEDA W. Potential force of infection of human rabies transmitted by vampire bats in the Amazonian region of Brazil. Am. J. Trop. Med. Hyg., 1996, 55, 680-4.

27 UIEDA W. Comportamento alimentar do morcego hematófago, Diaemus youngi, em aves domésticas. Rev. Bras. Biol., 1993, 53, 529-38.

28 UIEDA W., HARMANI NM., SILVA MM. Rabies in insectivorous bats (Molossidae) of Southeastern Brazil. Rev. Saúde Publ., 1995, 29, 393-7.

29 UIEDA W., HAYASHI MM., GOMES LH., SILVA MM. Espécies de quirópteros diagnosticadas com raiva no Brasil. Bol. Inst. Pasteur., 1996, 1, 17-35.

30 VELASCO-VILLA A., ORCIARI LA., JUÁREZ-ISLAS V., GÓMEZ-SIERRA M., PADILLA-MEDINA I., FLISSER A., SOUZA V., CASTILLO A., FRANKA R., ESCALANTE-MAÑE M., SAURI-GONZÁLEZ I., RUPPRECHT CE. Molecular diversity of rabies viruses associated with bats in Mexico and other countries of the Americas. J. Clin. Microbiol., 2006, 44, 1697-710.

31 WILLOUGHBY RE JR., TIEVES KS., HOFFMAN GM., GHANAYEM NS., AMLIELEFOND CM., SCHWABE MJ., CHUSID MJ., RUPPRECHT CE. Survival after treatment of rabies with induction of coma. N. Engl. J. Med., 2005, 352, 2508-14.

32 WORLD HEALTH ORGANIZATION. WHO expert consultation on rabies, first report. World Health Organ. Tech. Rep. Ser., 2005, 931, 1-88. 